\title{
Structural Health Monitoring Of Crude Oil Reservoir at the Forcados Terminal, Nigeria
}

\author{
R. Ehigiator - Irughe ${ }^{1}$, O.M. Ehigiator ${ }^{2}$, \\ ${ }^{I}$ GeoSystems and Environmental Engineering, 140 2nd East Circular Road, Benin city \\ ${ }^{2}$ Senior lecturer Faculty of Basic Science, Benson-Idahosa University, Benin City, Nigeria.
}

\begin{abstract}
In oil and Gas Companies, the safety of reservoir and their contents is of interest not only to the owners and operators but also to the public. This is as a result of the fact that if reservoirs were to fail and their content which is crude oil spilled into the environment, water will be polluted, biotic and aquatic lives will be affected. In the case of Nigeria the economy will be adversely affected. Most frequently used reservoir for crude oil storage in Nigeria are vertical cylindrical and of circular cross section. We present here methods and results of three epochs of geodetic inspection and the necessary computations that will reveal the character of the reservoir in Forcados, Nigeria.
\end{abstract}

Keywords: Tank, Oil Level, Radial Displacement, Ovality, Roof grap.

\section{Introduction}

As a result of serious environmental hazards resulting from reservoir failures there is need to carryout periodic monitoring of the reservoir. Above surface vertical cylindrical reservoir used in Oil and gas industries are constructed of steel and over the years many of the structures have corroded and leaked petroleum products into the soils thus contaminating ground water and the environment.

Leaking reservoir can be a source of groundwater problem as the petroleum which they carry contains toxic compounds including benzene, toluene, xylene and ethylene dibromide. These compounds are thought to cause cancer, and pose a number of health risks including nervous system damage, reproductive problem and immune system depression. The soils and geological condition at the structure locations can also affect ground water contamination.

\section{Crude Oil Storage Tanks At The Forcados Terminal}

Reservoirs at the Forcados terminal were constructed between 1967 and 1970. There are at the moment 10 crude oil storage reservoir each about $22 \mathrm{~m}$ in height and diameter $76.2 \mathrm{~m}$ (Fig. I).

The structural integrity of these reservoirs has been of major concern to both local community and environmentalists. Although API 653 remain the industry standard relative to reservoir inspection and maintenance, the frequency of testing and inspection can also be affected by various state and local regulations [1].

The schedule of this inspection process depend on a number of factors which include [2] the age, their proximity to groundwater, the leak records, the date of the last integrity test, the construction material used, the product stored, soil condition etc.

Reservoir at Forcados farm is bounded with a bound walls which measuring $250 \mathrm{~m}$ by $150 \mathrm{~m}$ and at a height of $12 \mathrm{~m}$. The bound walls are to accommodate and contain any spill that may result from failure of any of the reservoir.

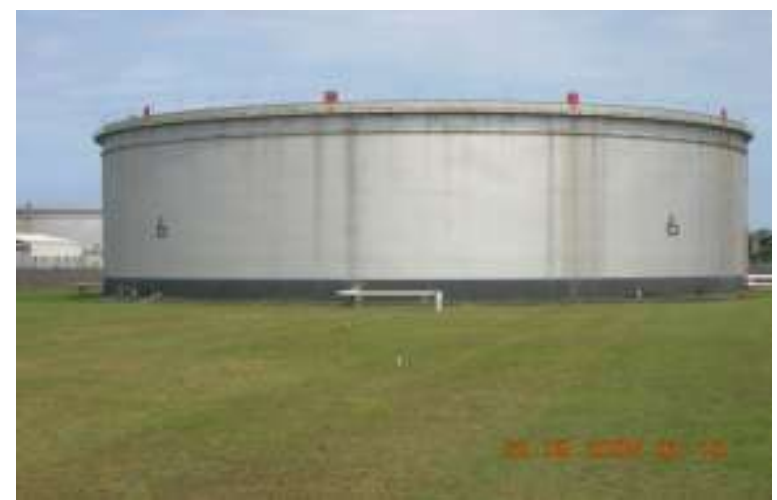

Figure 1: Reservoir at the Terminal 


\section{Structural Health Monitoring}

Reservoir used by oil Companies in Nigeria are cylindrical in shape. As a result of age, non-uniform settlement of the foundation, geological conditions loading and offloading, crude oil temperature, primary and secondary settlement of sediments results in radial deformation or out of roundness of the reservoir. This results in the binding of the floating roof or in cone-roof tanks displacement. Out of roundness may result in the upper shell course buckling. Shell out of roundness may result in gaps between reservoir shell and their hydrocarbon emission into the environment occurred. As a safety measure, each reservoir needs to be monitored periodically.

In this study, the monitoring conducted is geodetic measurement and include:

- Ovality measurement including establishment of controls for ovality checks

- Roof gap measurement to ascertain the integrity of the floating roof

- Verticality checks

- Reservoir Height determination.

\section{Ovality Survey}

These surveys were carried out from geodetic control points; monitoring stations were established close and around the reservoir to form well-conditioned triangles for intersection fix. The studs were then coordinated by angular intersection methods from these monitoring stations using total station instrument.

The stud coordinates were then computed using the intersection formula [3].

$$
\begin{aligned}
& \mathrm{E}_{\mathrm{s}}=\frac{\mathrm{E}_{\mathrm{A}} \operatorname{Cot} \mathrm{B}+\mathrm{E}_{\mathrm{B}} \operatorname{Cot} \mathrm{A}+\mathrm{N}_{\mathrm{A}}-\mathrm{N}_{\mathbf{B}}}{\operatorname{Cot} A+\operatorname{Cot} B} \\
& \mathrm{~N}_{\mathrm{s}}=\frac{N_{A} \operatorname{Cot} B+N_{B} \operatorname{Cot} A+E_{A}-E_{B}}{\operatorname{Cot} A+\operatorname{Cot} B}
\end{aligned}
$$

Where

$$
\mathrm{E}_{\mathrm{s}} \mathrm{N}_{\mathrm{s}} \text { - Easting and Northing of monitoring point (Stud) }
$$

$\mathrm{E}_{\mathrm{A}}, \mathrm{N}_{\mathrm{A}}-$ Easting and Northing coordinates of points $\mathrm{A}$ and $\mathrm{B}$ respectively. Angles $\mathrm{A}$ and $\mathrm{B}$ are the base angles of the intersecting lines.

The reservoir diameter can then be computed from coordinates of opposite studs using the equation (3).

$$
d=\sqrt{\left(X_{i}-X_{k}\right)^{2}+\left(Y_{i}-Y_{k}\right)^{2}}
$$

Where

$d$ is the reservoir diameter, $X$ and $Y$ are Easting and Northing of opposite studs, $i$ and $k$ as presented in Table 1.

Table 1: RESERVOIR DIAMETER

\begin{tabular}{|c|r|r|l|l|}
\multicolumn{1}{c|}{ Studs } & EASTING(m) & NORTHING(m) & DIAMETER(m) & RESIDUALS(m) \\
\hline STUD1 & 324845.63 & 148619.01 & & \\
\hline STUD9 & 324834.43 & 148543.4 & 76.432894 & 0.0283827 \\
\hline & & & & \\
\hline STUD16 & 324830.79 & 148618.38 & & \\
\hline STUD8 & 324848.53 & 148543.97 & 76.495553 & 0.0910415 \\
\hline & & & & \\
\hline STUD2 & 324859.7 & 148613.79 & & \\
\hline STUD10 & 324820.35 & 148548.38 & 76.333557 & -0.1118916 \\
\hline & & & & \\
\hline STUD4 & 324877 & 148590.08 & & 0.0910415 \\
\hline STUD12 & 324802.81 & 148571.89 & 76.379888 & \\
\hline & & & & \\
\hline STUD3 & 324871.06 & 148603.08 & & \\
\hline
\end{tabular}




\begin{tabular}{|c|r|r|r|l|} 
STUD11 & 324809.22 & 148558.39 & 76.29262 & -0.0246228 \\
\hline & & & & \\
\hline STUD5 & 324877.54 & 148575.14 & & \\
\hline STUD13 & 324802.08 & 148586.8 & 76.364426 & -0.0400851 \\
\hline & & & & \\
\hline STUD7 & 324862.19 & 148550.16 & & \\
\hline STUD15 & 324817.24 & 148612.06 & 76.499612 & 0.0330286 \\
\hline & & & & \\
\hline STUD6 & 324872.37 & 148561.1 & & \\
\hline STUD14 & 324807.11 & 148600.9 & 76.43754 & 0.0951009 \\
\hline Average & & & 76.404511 & \\
\hline
\end{tabular}

The coordinate of the centre of the reservoir is given as

$$
\left(X_{c}-Y_{c}\right)^{2}=(d / 2)^{2}-\left(X_{i}-Y_{i}\right)^{2}
$$

Where

$X_{c}$ and $Y_{c}$ are the coordinates of the centre, $X_{i}$ and $Y_{i}$ are coordinates of the studs.

Figure (2) is the reservoir ovality computed using equations (1) and (2) respectively, while figure (3) is the diameter.

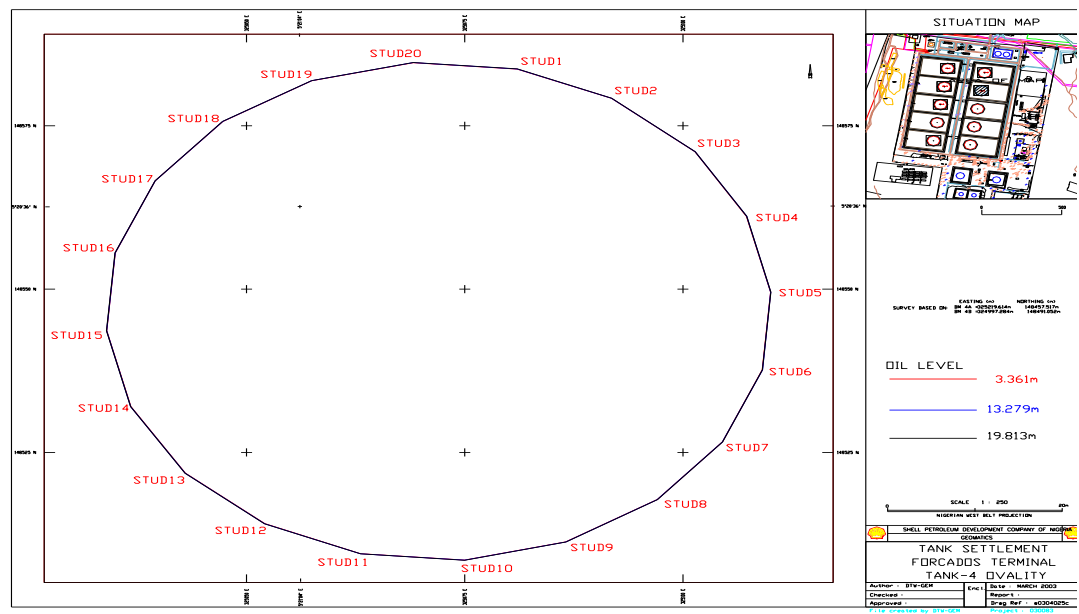

Figure 2: Reservoir Ovality
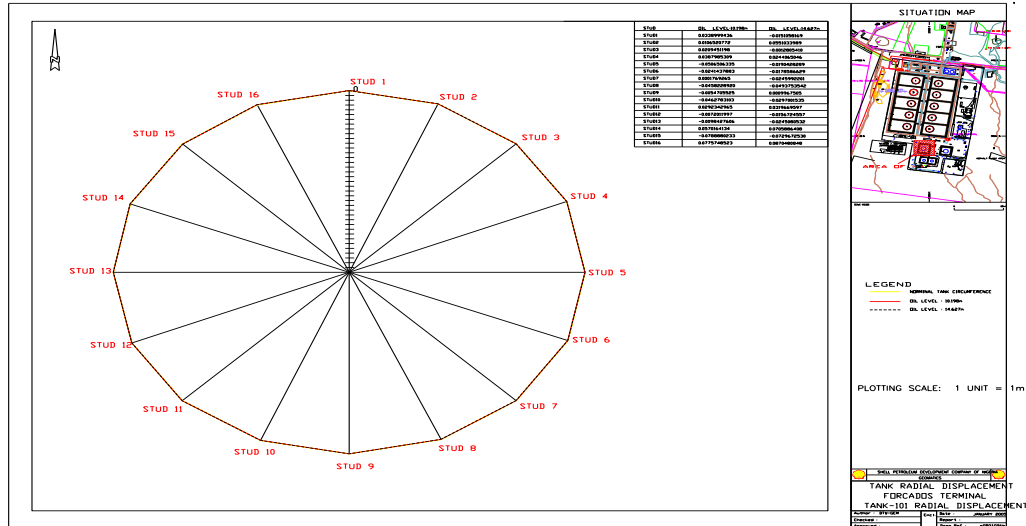

Figure 3: Reservoir Diameter

V. Determining Of The Tank Wall Distortion

Each point on the perimeter of cross section of reservoir must fulfill the equation of circle as given in equation (4) above. By using the resulted values of radius $\boldsymbol{r}$ and coordinates of center $\left(\boldsymbol{X}_{\boldsymbol{C}}, \boldsymbol{Y}_{\boldsymbol{C}}\right)$, the distortion of each monitoring point can be determined by using the following formula [4]: 


$$
\mathrm{f}_{\mathrm{i}}^{\mathrm{dist} .}=\sqrt{\left(\mathrm{X}_{\mathrm{i}}-\mathrm{X}_{\mathrm{C}}\right)^{2}+\left(Y_{i}-Y_{C}\right)^{2}}-r
$$

By determining the distortion of each point on the circular cross section of the reservoir, the actual deformed shape of the reservoir can be determined as presented in table 2 .

Table 2: RESERVOIR № 2 DISTORTION

\begin{tabular}{|l|c|c|c|}
\hline \multirow{2}{*}{$\begin{array}{c}\text { Monitoring point on the } \\
\text { tank surface }\end{array}$} & \multicolumn{3}{|c|}{$\begin{array}{c}\text { Distortion, } \mathrm{mm} \\
\mathrm{r}_{\mathrm{i}}-\mathrm{r}_{\text {act. }}\end{array}$} \\
\cline { 2 - 4 } & Year 2003 & Year 2004 & Year 2008 \\
\hline STUD 6 & -18.25 & -11.65 & 6.13 \\
\hline STUD 16 & 36.78 & 6.38 & 133.65 \\
\hline STUD 7 & 29.63 & -18.86 & 8.19 \\
\hline STUD 17 & 48.19 & 30.45 & 89.34 \\
\hline STUD 8 & -53.20 & -42.15 & -10.24 \\
\hline STUD 18 & 40.87 & 34.96 & 82.98 \\
\hline STUD 9 & -26.65 & -21.56 & 4.31 \\
\hline STUD 19 & 11.36 & 12.59 & 51.48 \\
\hline STUD 10 & -45.02 & -44.77 & -9.73 \\
\hline STUD 20 & 9.14 & 15.94 & 45.28 \\
\hline STUD 11 & -39.99 & -49.72 & -5.39 \\
\hline STUD 1 & 4.77 & 17.93 & 46.16 \\
\hline STUD 12 & -6.18 & -24.58 & 74.20 \\
\hline STUD 2 & 11.51 & 40.39 & 61.14 \\
\hline STUD 13 & 9.80 & 4.94 & 17.96 \\
\hline STUD 3 & 9.13 & -6.21 & 8.31 \\
\hline STUD 14 & 12.72 & 12.79 & 55.71 \\
\hline STUD 4 & -44.04 & -35.87 & -14.35 \\
\hline STUD 15 & 32.98 & 9.11 & 110.73 \\
\hline STUD 5 & -32.78 & -16.41 & 0.67 \\
\hline $\begin{array}{l}\text { Maximum distortion value, } \\
\text { mm }\end{array}$ & $\mathbf{4 8 . 1 8 5}$ & $\mathbf{4 0 . 3 9 2 9}$ & $\mathbf{1 3 3 . 6 4 9 5}$ \\
\hline $\begin{array}{l}\text { Minimum distortion value, } \\
\text { m }\end{array}$ & $\mathbf{- 5 3 . 2 0 0 6}$ & $\mathbf{- 4 9 . 7 1 7 9}$ & $\mathbf{- 1 4 . 3 5 0 2}$ \\
\hline
\end{tabular}

Note that the sign (+) in table indicate larger radius hence the reservoir is said to have expansion. The sign (-) indicate smaller radius hence the tank is said to contracting.

From the resulting data, the actual deformed shape of the circular cross section can be drawn easily. We present the deformation shape of reservoir №. 2 distortions using the data above and the nominal diameter in fig $(4)$.

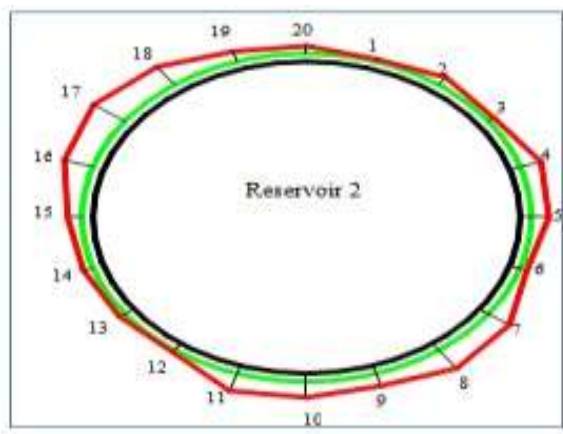

Norminal Diameter $76.2 \mathrm{~m}$

Reservoir shape in 2008

Deformation value in 2008

Figure 4: The deformed shape of reservoir №. 2 in 2008 
By the same way, the actual deformed shape of any circular cross section of any reservoir can be drawn.

\section{Determining the height of circular oil tanks}

The instrument is placed at distance from the monitored structure that permits the instrument to observe the highest and lowest point of the reservoir. The horizontal distance from the instrument to the reservoir is measured by using Total station.

By using the measured vertical angles $\gamma_{1}, \gamma_{2}$ and the horizontal distance $\mathrm{D}$, the height $\mathrm{H}$ can be measured by applying the formula (6):

$$
H=D\left(\tan \gamma_{1}+\tan \gamma_{2}\right)
$$

The measure slope distance $S_{i}$, most be reduced to horizontal distance (D) using equation (7) below

$$
D=s_{i} \sin \gamma_{i}
$$

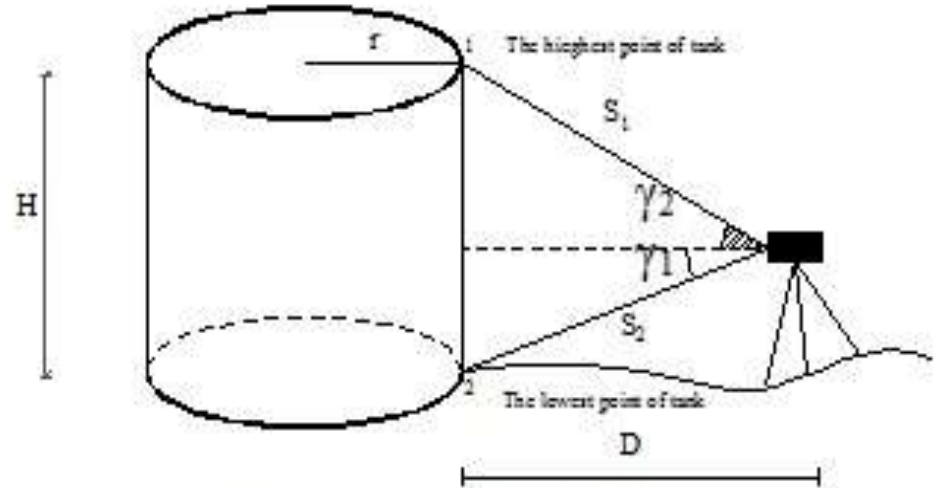

Fig. 5: Height by theodolite Angles

\section{Verticality Surveys}

Method of verticality measurement using reflectorless total station is presented below.

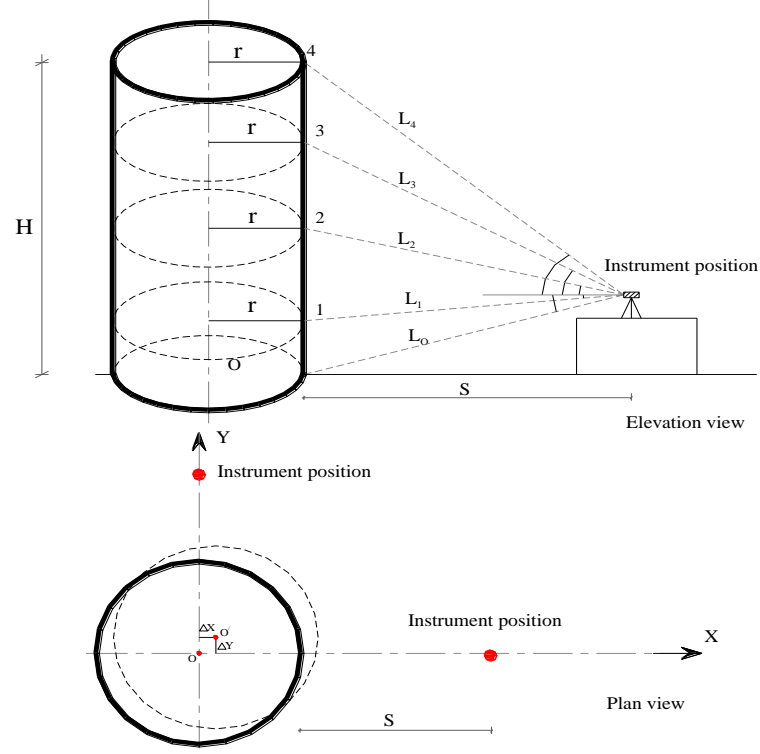

Figure 6: The geometry of determination the inclination of circular engineering structures with constant diameter

The total station is positioned near the structure at distance (S) from its base, where it can sight the full height of the monitored structure. The inclined distance and vertical angles from the instrument to each 
horizontal section which are distributed at specified heights along the tank height must be measured. In our study, reservoir verticality of studs location in the North, East, South and west of the reservoir where determined.

At any section (i) along the height of structure, the inclination $\Delta_{\mathrm{i}}$ can be determined as following: [7]

$$
\Delta_{i}=D_{i} \cos \gamma_{i}-D_{0} \cos \gamma_{0}
$$

Horizontal distance (D) can be determined using equation (7)

Inclined angle $\tan (\varphi)=\frac{\Delta_{i}}{H_{i}}$

Where $\mathrm{L}_{0}-$ the inclined distance from the instrument to the Tank base; $\mathrm{L}_{\mathrm{i}}-$ the inclined distance from instrument to section i; $\gamma_{0}, \gamma_{\mathrm{i}}-$ vertical angle at base and section i respectively. There is vertical deflection if $\Delta$ is greater than $\pm 0.002 \mathrm{H}$. $\mathrm{H}$ may be segmented height or the full height of the structure. Table 2 is the reservoir inclination and figure (7) is cross section of reservoir under study at two Oil reservoir levels.

Table 2: Reservoir inclination

\begin{tabular}{|l|l|l|l|l|l|}
\hline TANK2 & O/L $19 \mathrm{~m}$ & O/L $10 \mathrm{~m}$ & O/L $19 \mathrm{~m}$ & $\mathrm{O} / \mathrm{L} 10 \mathrm{~m}$ & Remark \\
\hline STUDS & $\begin{array}{c}\text { Inclined } \\
\text { angle }\end{array}$ & $\begin{array}{c}\text { Inclined } \\
\text { angle }\end{array}$ & $\begin{array}{c}\text { Inclinatio } \\
\mathrm{n}(\mathrm{m})\end{array}$ & $\begin{array}{c}\text { Inclinatio } \\
\mathrm{n}(\mathrm{m})\end{array}$ & $0.002 \mathrm{H}=0.004$ \\
\hline STUD8 & $0^{0} 20^{\prime} 38^{\prime \prime}$ & $-0^{0} 01^{\prime} 59^{\prime}$, & 0.132 & -0.013 & No tilt \\
\hline STUD4 & $-0^{0} 03^{\prime} 48^{\prime \prime}$ & $-0^{0} 11^{\prime} 13^{\prime \prime}$ & -0.024 & -0.072 & Tilted \\
\hline $\begin{array}{l}\text { STUD1 } \\
6\end{array}$ & $-0^{0} 01^{\prime} 16^{\prime \prime}$ & $-0^{0} 04^{\prime} 53^{\prime \prime}$ & -0.008 & -0.031 & No tilt \\
\hline $\begin{array}{l}\text { STUD1 } \\
2\end{array}$ & $0^{0} 20^{\prime} 10^{\prime \prime}$ & $0^{0} 07^{\prime} 36^{\prime}$, & 0.129 & 0.049 & Tilted \\
\hline
\end{tabular}

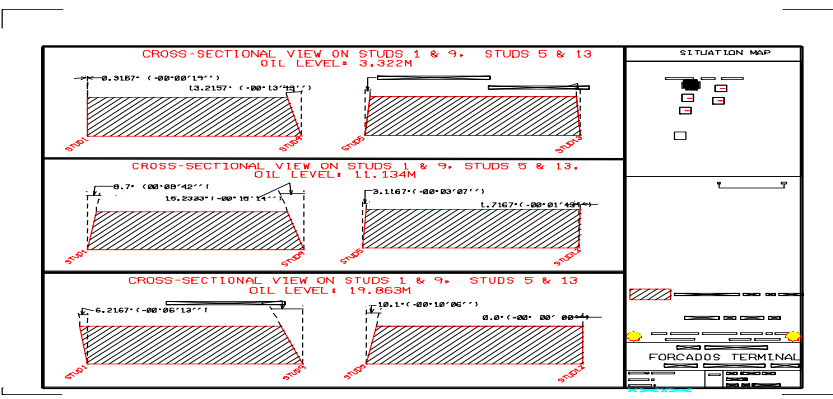

Figure 7: Cross - section of verticality check

VIII. Roof Gap Measurement

To measure the roof gap, the circumference of the tank was sub divided into equal interval using diametrically opposite studs. Measurements are taken between the studs with the aid of a calibrated metric tape and hence diameter of the tank was physically measured.

\section{Conclusions}

The history of tank disaster throughout the world reveals that problems often arise undetected due to inaccurate evaluation of both foundation and structural defects. The soil, water and concrete at the foundation bed are materials of different properties. The level of interaction cannot be underestimated. Although the interaction is not spontaneous, the solvent property of water can undermine the configuration of the soils upon which the structure rests.

Monitoring and inspection of crude oil reservoir will ensure continuous safety of the structure so as to avoid the danger arising from environmental degradation as a resulting from structural failure.

Monitoring of the tanks should be carried out more frequently for early detection of symptoms and deficiencies and remedial measures taken as quickly as possible. 


\section{References}

[1] Ehigiator - Irughe, R. and Ehigiator M. O.(2010). Estimation of the centre coordinates and radius of Forcados Oil Tank from Total Station data using least square Analysis" International Journal of pure and applied sciences. A pan - African Journal Series.

Ehigiator - Irughe, R. Ashraf A. A. Beshr, J.O. Ehiorobo and O.M. Ehigiator (2011). Modification of Geodetic Methods for Determining the Monitoring Station Coordinates on the Surface of Cylindrical Oil Storage Tank. Research Journal of Engineering and Applied Sciences (RJEAS) 1 (1) pp. 58 - 63. A United State Academy publications USA.

[2] Ehigiator - Irughe, R. Ashraf A. A. Beshr, and Ehigiator M. O.(2010)

[3] Structural deformation analysis of cylindrical oil storage tank using geodetic observations. (Paper Presented at Geo -Siberia 2010, International Exhibition and scientific conference VI page 34 - 37, Novosibirsk, Russia Federation.

[4] Ehigiator - Irughe, R. Ehiorobo O. J and Ehigiator M. O.(2010)

[5] Methods of Verticality Measurement of Crude Oil Storage Tanks. publication in International Journal of pure and Applied sciences. A pan - African Journal Series IV pp 20-23)

[6] Ehigiator - Irughe, R. J.O. Ehiorobo, O.M. Ehigiator and Ashraf A. A. Beshr (2011)

[7] Determining the Subsidence of oil Tank walls from Geodetic Levelling. Advanced Material Research Vol. 367 pp. 467 - 474. Tran's publication, Switzerland.

[8] Shell Petroleum Development Company of Nigeria (2000): http://www.nigerianoil- gas.com/industry profile

[9] Shell Petroleum Development Company (2003): Oil Industry profile, Nigeria. http://www.nigerianoil-gas.com/industryprofile

[10] World Health Organization WHO Report (2003) Environmental Hazards and the Oil Industry About we visit: www.geosystems2004.com 